\title{
Cost of Debt and Federal Home Loan Bank Funding at U.S. Bank and Thrift Holding Companies
}

Scott Deacle

Ursinus College, sdeacle@ursinus.edu

Elyas Elyasiani

Temple University

Follow this and additional works at: https://digitalcommons.ursinus.edu/bus_econ_fac

Part of the Economics Commons, Finance and Financial Management Commons, Portfolio and Security Analysis Commons, and the Real Estate Commons

Click here to let us know how access to this document benefits you.

\section{Recommended Citation}

Deacle, Scott and Elyasiani, Elyas, "Cost of Debt and Federal Home Loan Bank Funding at U.S. Bank and Thrift Holding Companies" (2016). Business and Economics Faculty Publications. 28.

https://digitalcommons.ursinus.edu/bus_econ_fac/28

This Article is brought to you for free and open access by the Business and Economics Department at Digital Commons @ Ursinus College. It has been accepted for inclusion in Business and Economics Faculty Publications by an authorized administrator of Digital Commons @ Ursinus College. For more information, please contact aprock@ursinus.edu. 


\title{
Cost of Debt and Federal Home Loan Bank Funding At U. S. Bank and Thrift Holding Companies
}

Running Title: Cost of Debt and FHLB Funding at BHCs and THCs

\author{
Scott Deacle \\ Ursinus College \\ Bomberger Hall 308 \\ Collegeville, PA 19426 \\ sdeacle@ursinus.edu \\ Elyas Elyasiani (Corresponding) \\ Fox School of Business and Management \\ Temple University \\ Alter Hall 413 \\ Philadelphia, PA 19122 \\ elyas@temple.edu
}

This version: February 29, 2016

\begin{abstract}
We investigate the relationship between the cost of debt issued by bank and thrift holding companies (BHCs, THCs) and their use of Federal Home Loan Bank (FHLB) advances. Cost of debt is used as a measure of bank riskiness for the first time in a FHLB study. A twoequation model of FHLB advances and cost of debt is estimated. Three main results are obtained. First, greater reliance on advances by BHCs and THCs is associated with lower cost of debt in the pre-crisis period, and more strongly so during the crisis, because granting of advances sends a positive signal to the market about FHLB's support. Second, greater HC cost of debt, as an explanatory variable, is associated with smaller advances as FHLBs restrict advances to riskier HCs. Third, we find no separate effect on the cost of debt from FHLB membership. Our results are robust to 3SLS estimation, used to address endogeneity, and to alternative model specifications. The negative association between cost of debt and advances suggests that BHCs and THCs do not use advances to make riskier loans and that FHLB policies and services have some risk-reducing effects which more than offset the effect of potential moral hazards.
\end{abstract}

JEL Classification: G2, G21, G23, G01. Keywords: Federal Home Loan Banks (FHLB); GSE; Advances; Mortgages; Risk; Cost of Debt; Bank and thrift Holding Companies. 


\section{Cost of Debt and Federal Home Loan Bank Funding At U.S. Bank and Thrift Holding Companies}

\section{Introduction}

The Federal Home Loan Bank (FHLB) system is one of the largest sources of funding and liquidity to the U.S. mortgage market. At the peak of the recent financial crisis (Q3-2008), FHLBs reported outstanding loans, called advances, of about $\$ 1$ trillion to their members. By comparison, fellow housing-related government-sponsored enterprises (GSEs), Fannie Mae and Freddie Mac, reported total assets of $\$ 894$ billion and $\$ 804$ billion, respectively. ${ }^{1}$ This crisis made it plainly evident that the U.S. mortgage market can exert a substantial impact on the U.S. and world financial markets. It follows that the behaviour of the FHLBs, as major players in this market, can significantly influence the largest world economies.

Researchers differ on whether the FHLBs increase or decrease the financial system's risk. Nickerson and Phillips (2004) and Stojanovic, Vaughan, and Yeager (2008) argue that FHLBs allow their members to increase their risk by providing them with additional funds to make risky loans that they otherwise would not have been able to make (moral hazard). According to these authors, by taking advances, FHLB members can make risky loans while avoiding market discipline through higher-cost debt because interest rates on advances are the same, regardless of member riskiness. ${ }^{2}$

In contrast, Scott and Hein $(2011,2009)$ propose that FHLBs reduce bank risk through advances-based collateral requirements and required purchase of FHLB stock, rationing of advances to riskier members, FHLB-provided risk management services, and the use confidential regulatory information to make decisions about advances. Moreover, regulators can take

\footnotetext{
${ }^{1}$ Crisis period is defined in section 4. For description of the stages of the crisis see Gorton (2010), Mishkin (2011).

${ }^{2}$ Interest rates on advances do not vary among borrowers within individual FHLBs, but they do vary across FHLBs. Each FHLB determines its own interest rates on advances.
} 
supervisory actions to deter FHLBs from lending to risky members. Advances may also reduce risk during credit crunches when they are made available to healthy banks. These forces tend to counterbalance the forces that could lead to a positive relationship between advances and risk. The net effect of the above countervailing powers is an empirical question that we seek to investigate in this paper. Our approach is to use yield spreads on bank holding company (BHC) and thrift holding company (THC) bonds as a market-based measure of their risk and to examine whether, controlling for other factors, FHLB membership and advances are associated with higher or lower yield spreads.

This study has four objectives. First, we investigate the relationship between BHCs' and THCs' dependence on FHLB advances and their cost of uninsured debt, a measure of risk. This provides evidence regarding competing theories of the association between FHLB advances and member HCs' risk. Second, we examine the relationship between FHLB membership, independent of advance-taking, and FHLB members' cost of debt. Markets may price different risk premia on debts issued by HCs that have an FHLB-member subsidiary, regardless of the size of the advances taken by the subsidiary. Third, we investigate the association between the level of advances utilized as the explained variable and $\mathrm{HC}$ riskiness to determine whether FHLBs curtail advances to riskier members (risk-based rationing). Fourth, we investigate whether the aforesaid relationships intensified during the financial crisis of 2007-2009.

Our contributions include the following. First, we use market data to develop a measure of HC risk, the yield spread on HC bonds. Previous research has relied on accounting-based risk measures which are backwards looking, lack information about systemic or macroeconomic risk, and are influenced by 'window dressing'. Market-based risk measures reflect investors' knowledge of economy-wide conditions, expectations of future HC performance, and other 
information that $\mathrm{HC}$ managers do not release in financial statements. Second, using bond market data, rather than stock market data, has advantages that bonds have well-defined future payoffs and empirical results based on bond pricing models are less likely to be driven by model misspecification, than stock valuation models (Klock, Mansi, and Maxwell 2005; Deng Elyasiani, and Mao 2007; Kim, Li, and Li 2012). ${ }^{3}$ The bond market also merits attention because of its growing size. According to the Securities Industry and Financial Markets Association (SIFMA, 2012), between 1990 and 2011, new debt issuance in the U.S. increased from \$169 billion to $\$ 1.178$ trillion while new equity issuance increased from $\$ 24$ billion to $\$ 198$ billion.

Third, we complement bank data with thrift data. Most studies on the relationship between FHLBs and their members have focused on commercial banks alone. Inclusion of thrifts widens the sample and allows us to test for differential behavioural patterns of the two groups, which until recently were overseen by separate regulatory authorities. Fourth, we measure variables at the HC level, while previous research has employed subsidiary-level data. The latter studies may under- or overestimate the risk of individual banks and thrifts because parent HCs may shift risk among their subsidiaries. Finally, we allow for the possibility of a simultaneous relationship between risk and reliance on FHLB advances by using a system model and estimating it using simultaneous-equation methods.

We obtain several interesting results. First, reliance on advances is associated with a lower cost of debt in the pre-crisis period and the association strengthens during the crisis (Q3-2007 to Q1-2009). The former result is consistent with a special case of Stojanovic, Vaughan, and Yeager's (2008) theoretical model and with the findings of Scott and Hein $(2011,2009)$. In economic terms, the magnitude of the effect is equivalent to an $\$ 896,000$ reduction of the annual interest payment on the mean bond issue-size in the sample (\$320 million) in the pre-crisis

\footnotetext{
${ }^{3}$ Jagtiani and Lemieux (2001) have found that BHC bond spreads rise as early as six quarters prior to their failure. 
period, and a reduction of $\$ 1,325,120$ in the crisis period. As expected, the market places greater value on FHLB funds during the crisis because it signals FHLB's willingness to support the borrowing bank and reduces the bank's probability of bankruptcy.

Second, increased cost of debt is associated with a decline in the reliance on advances, as the explained variable, both before and during the crisis. This might reflect rationing by the FHLBs when FHLB member riskiness rises. It may also reflect members' avoidance of FHLB advances when they feel tightness in the market, in anticipation of stricter terms from FHLBs. Third, as proposed by Stojanovic, Vaughan, and Yeager's (2008) model, the cost of debt and reliance on advances demonstrate bidirectional interdependence. Fourth, FHLB membership, independent of advances, does not significantly influence the cost of debt throughout the sample. Fifth, THCs' cost of debt is significantly higher than that of BHCs, and more so during the crisis.

In what follows, Section 2 reviews the relevant literature and presents the hypotheses, Section 3 describes the model and the estimation techniques, Section 4 discusses the data and sample selection, Section 5 reports the results, and Section 6 concludes.

\section{Background, Literature Review and Theory}

Congress and President Hoover created the FHLB system in 1932, during the Great Depression, to enhance liquidity in the mortgage market. ${ }^{4}$ This system now includes 11 FHLBs, each of which is owned primarily by private financial intermediaries (FIs) and governed by a board of directors. Following changes enacted by Congress in the 1980s and 1990s, FHLB membership is available to most U.S. depository institutions as well as public housing authorities and life insurance companies. According to Federal Housing Finance Agency (FHFA) data, system membership rose from about 3,200 institutions in 1989 to 7,258 in the third quarter of

\footnotetext{
${ }^{4}$ Hoffmann (2001) summarizes the legislative history of the FHLBs.
} 
2015. The latter figure includes nearly all thrifts and about $75 \%$ of commercial banks in the U.S. Though FHLBs have some discretion over their policies, they have always been federally regulated, first by the Federal Home Loan Bank Board, from 1932 to 1989, next by the Federal Housing Finance Board (FHFB), from 1989 to 2008, and then by the FHFA since 2008.

A central Office of Finance issues bonds for the entire FHLB system. Individual FHLBs bear joint and several liability for the debt, meaning they are each and all responsible for repaying the debt incurred by the Office of Finance. Investors require lower interest rates on FHLB debt, than on debt issued by private FIs with otherwise comparable risk characteristics, because FHLBs are granted a line of credit at the Treasury and their debt is eligible for Federal Reserve open market purchases. Additionally, the Competitive Equality Banking Act (1987) grants FHLBs a 'super lien' that gives them priority over other creditors if an FHLB member fails. These privileges reduce FHLB system's default risk, increase its debt's liquidity and contribute to the perception of an implicit federal guarantee of FHLB debt. Ambrose and Warga (2002) and Nothaft, Pearce, and Stevanovic (2002) present evidence of lower interest rates conferred by these privileges. FHLBs pass the savings to their members by charging relatively low interest rates on advances. FHLBs also provide members emergency funding during credit crunches. For example, Ashcraft, Bech, and Frame (2010) write that in the second half of 2007, after the three major credit rating agencies downgraded subprime mortgages-backed securities, FHLBs increased advances by $36.7 \%$ from $\$ 640$ billion to $\$ 875$ billion.

Several authors have argued that flawed FHLB regulations and policies allow FHLB members to use advances to fund risky loans. This can happen because FHLB members lack strong incentives to monitor FHLB lending to other members, FHLB managers lack strong incentives to monitor one another, and FHLBs charge the same interest rates on advances to all 
borrowers, regardless of risk. Ashley, Brewer, and Vincent (1998) compare advance taking by thrifts that were insolvent, reorganized, or closed during the 1980s thrift crisis. They find that advances as a percentage of total assets, were, ceteris paribus, higher at the former group of thrifts. Nickerson and Phillips (2004) find similarities between the FHLB system and the U.S. farm credit system, which the federal government bailed out in the 1980s; the institutions comprising the two systems bear joint and several liability for their system's debt, and the two systems share similar rules on member stock ownership.

On the other hand, some researchers argue that a cooperative structure like the one used by the FHLBs can mitigate risk. For example, Stiglitz (1990) and Ghatak and Guinnane (1999) present theories of cooperative borrowing in which joint liability reduces credit risk. However, citing a theory of group borrowing presented in Che (2002), Nickerson and Phillips (2004) argue that such risk reduction does not accrue to the FHLB system because individual FHLBs can obtain new debt from the Office of Finance without direct permission from other FHLBs. Flannery and Frame (2006) argue that member ownership of individual FHLBs does not reduce risk-taking incentives because FHLB shares are not tradable and require six months to five years notice to sell. FHLB members are, thus, unable to easily exercise equity market discipline.

Stojanovic, Vaughan, and Yeager (2008) propose a model of FHLB funding in which FHLB members' reliance on advances and risk are jointly determined and have a bidirectional relationship. However, using bank-level accounting data, they find that increased reliance on advances is not associated with economically significant increases in most of the risk measures they consider. In some cases, it is associated with lower risk. For example, they find no economically significant relationship between borrowing banks' credit risk and advances to total assets ratios. They find a negative relationship between reliance on advances and interest rate 
risk. Moreover, they find no difference between members' and non-members' probability of failure as measured by Federal Reserve examination scores. These authors find, however, that after banks become FHLB members, they exhibit significant increases in liquidity and leverage risks. Stojanovic, Vaughan, and Yeager's sample includes subsidiary-level banks, meaning that their results may have been affected by risk-shifting among subsidiaries by BHC managers. In addition, their sample covers 1992-2005, a relatively quiet period in U.S. banking.

The theoretical model and the empirical findings of Stojanovic, Vaughan, and Yeager (2008) and the arguments put forward by Scott and Hein $(2011,2009)$ suggest that FHLB member banks' risk may be negatively associated with advance-taking and FHLB membership. FHLBs are required to satisfy the relevant federal regulations such as a mandate to submit capital plans to their regulator. These plans generally require FHLB members to purchase more stock as they use more advances. Scott and Hein (2011) argue that because of these activity-based stock purchases, changes in the size of the FHLB balance sheets are self-capitalizing as they leave leverage unchanged for this line of business. Activity-based capital requirements also raises the opportunity cost of advances, aligns the interests of borrowing banks and FHLBs, and motivates banks to protect their own safety in order to protect the FHLBs' safety. Both forces curtail the growth in bank risk engendered by the low cost of advances (moral hazard). ${ }^{5,6}$

Second, Scott and Hein $(2011,2009)$ describe several checks on advance taking. For example, FHLBs set limits on member advance-taking, frequently in the range of $40 \%$ to $50 \%$ of members' assets. Third, FHLB officers have access to confidential regulatory examination

\footnotetext{
${ }^{5}$ Federal Home Loan Bank Office of Finance (2010). Discussion of the FHLBanks' Capital Structure and Regulatory Capital Requirements (http://www.fhlb-of.com/ofwebuserWeb/resources/capitalqanda.pdf). See also Capital Plan of the Federal Home Loan Bank of Pittsburgh (2010) (http://www.fhlb-pgh.com/pdfs/capitalplan/capplanpgh.pdf. ${ }^{6}$ Capital requirement by the FHLBs is not identical to ordinary capital as losses are not charged against them, but it does provide an incentive to the borrowing banks to behave cautiously. Managerial ownership is known to exert a similar effect in aligning the shareholder and managers' interests, limiting the agency costs as a result.
} 
reports which prompts them to take steps to curb members' risk. Fourth, when FHLB members show signs of increasing default risk, FHLBs may halt new advances, require them to post additional collateral, and take 'physical possession' of the collateral through a custodial service. Managers of FHLB-member FIs know, therefore, that they could suffer a reduction in advances if they appear too risky to their FHLB's officers. Fifth, FHLBs provide smaller members with risk management resources, such as interest rate swaps, that they otherwise could not access or afford. Finally, FHLBs offer advances with maturities as long as thirty years and emergency funding in credit crunches, both of which lower members' liquidity risk.

In summary, previous research shows that several opposing forces drive the relationship between BHC and THC risk on the one hand and FHLB membership and reliance on FHLB advances on the other. If FHLBs generally lend more leniently to safer members and more strictly to risky members, bond market participants would perceive greater FHLB advances as a sign of FHLB confidence in the member. This would result in lower cost of debt. However, If FHLBs are not strict in screening borrower risk, and banks and thrifts use FHLB advances to avoid market discipline through higher cost of debt, advances and cost of debt may demonstrate a positive relationship. Thus, we propose our first hypothesis $\mathrm{H}_{1}$ as:

$\mathbf{H}_{1}$ : Greater reliance on advances is associated with lower $\mathrm{HC}$ cost of debt.

When the mortgage crisis began in Q3-2007, investors became more sensitive to the downside risks associated with mortgage-backed securities (MBS). If a negative relationship existed between FHLB advances and HC cost of debt before the crisis, it may have strengthened afterwards because FHLB support is more critical during crises. Moreover, FHLBs could show greater sensitivity to riskiness of the members during the crisis and could further restrict 
advances granted to risky members, driving up the cost of their uninsured debt in the marketplace. Therefore, we propose hypothesis $\mathrm{H}_{2}$ :

$\mathbf{H}_{2}$ : The negative relationship between $\mathrm{HC}$ cost of debt and reliance on advances strengthened during the crisis (Q3-2007 to Q1-2009).

FHLB membership, independent of advance-taking, may also be associated with lower cost of debt because of the risk-mitigation resources, such as interest rate swaps, provided to FHLB members, that they could not otherwise obtain, access of FHLB members to emergency funding in credit crunches, and access to advances with maturities of up to 30 years that may make FHLB membership valuable to debt holders. We use a data set containing HCs that control FHLBmember subsidiaries and $\mathrm{HCs}$ that do not, to test hypothesis $\mathrm{H}_{3}$ below within a multiple regression framework. Moreover, we investigate whether the relationship between cost of debt and FHLB membership strengthened during the crisis, hypothesis $\mathrm{H}_{4}$ :

$\mathbf{H}_{3}$ : FHLB membership is associated with a lower cost of debt.

$\mathbf{H}_{4}$ : The negative relationship between HC cost of debt and FHLB membership strengthened during the crisis (Q3-2007 to Q1-2009).

The relationship between advances and cost of debt may be bidirectional in the sense that increased cost of debt (risk) may also impact the level of advances available to the FHLB member. In particular, when a FHLB member becomes riskier, the FHLB may curtail advances, creating an inverse relationship between the two variables. This relationship may strengthen during the financial crisis, if the FHLB becomes more sensitive to the risk behaviour of its members. Thus, we propose the following hypotheses:

H5: $_{5}$ Increased riskiness of a FHLB member is associated with a lower level of advances.

$\mathbf{H}_{6}$ : The negative relationship between advances and a $\mathrm{HC}$ cost of debt strengthened during the crisis (Q3-2007 to Q1-2009). 


\section{Econometric Models}

We specify a two-equation system model that allows the $\mathrm{HC}$ cost of debt and reliance on advances by the bank/thrift subsidiary to be jointly determined. The model is described by equations (1) - (2), the components of which will be defined below:

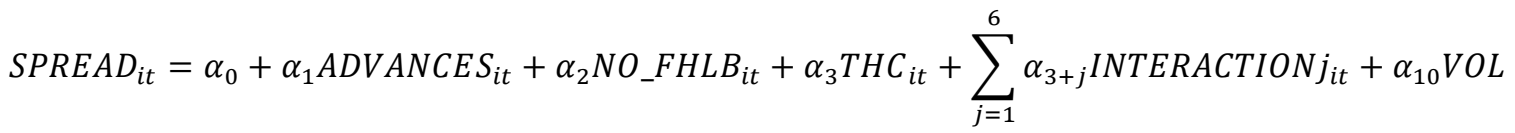

$$
\begin{aligned}
& +\alpha_{11} R O A_{i t}+\alpha_{12} \text { SIZE }_{i t}+\alpha_{13} D I_{-} F O C U S_{i t}+\alpha_{14} A G E_{i t}+\alpha_{15} I_{S S U E \_S I Z E_{i t}}+\alpha_{16} \text { CALL }_{i t} \\
& +\alpha_{17} \text { PUT }_{i t}+\alpha_{18} \text { SENIOR }_{i t}+\alpha_{19} \text { CRISIS }+\lambda_{1} \text { SPREAD } D_{i t-1}+\varepsilon_{i t} \\
& A D V A N C E S_{i t}=\gamma_{0}+\gamma_{1} S P R E A D_{i t}+\gamma_{2} \text { CRISIS } * S P R E A D_{i t}+\gamma_{4} \text { CORE }_{i t}+\gamma_{4} L_{-} D_{-} A T I O_{i t}+\gamma_{5} \text { SIZE }_{i t} \\
& +\gamma_{6} N_{-} \text {FHLB }_{i t}+\gamma_{7} \text { MAT }_{i t}+\gamma_{8} \text { CRISIS }_{i t}+\lambda_{2} \text { ADVANCES } S_{i t-1}+v_{i t}
\end{aligned}
$$

In this model, cost of debt and reliance on advances are proxied by the bond yield spread of the parent HC (SPREAD) and advances to total liabilities ratio (ADVANCES), respectively.

$S P R E A D$ is modeled as a function of the following variables: ADVANCES; a binary variable $\left(N O_{-} F H L B\right)$ that equals one if the bond-issuing HC does not control an FHLB-member subsidiary; a binary variable representing the financial crisis (CRISIS), a thrift binary (THC) that equals one if the bond-issuing $\mathrm{HC}$ is a THC; a set of pair-wise interaction terms between ADVANCES, NO_FHLB, and THC with the crisis binary; a set of control variables used in existing studies; and the one-period lagged value of SPREAD. Following Deng, Elyasiani, and Mao (2013), the crisis period starts in Q3-2007, when ratings agencies slashed credit ratings on subprime MBS and two Bear Stearns hedge funds heavily invested in MBS were declared worthless. It ends in Q1-2009 when the stock market started its rebound.

Lagged values of the dependent variables (SPREAD) are included because SPREAD and $A D V A N C E S$ may require time to reach equilibrium following changes in their respective determinants. In the case of SPREAD, this could occur because of infrequent bond trading and 
slow adjustment of prices in response to new market perception of risk. In addition, regulatory reports containing data on $\mathrm{HC}$ advances, liabilities, and other variables, are released about 45 to 60 days after the end of each quarter. For $A D V A N C E S$, multi-period adjustment may be a result of prepayment penalties and other restrictions that slow the adjustment of advances and other debt instruments in a HC funding mix. Partial-adjustment models produce estimates of both short-run and long-run effects of changes in the independent variables on the dependent variable.

The interaction terms are constructed in two steps: (1) we multiply the variables of interest, (ADVANCES, NO_FHLB, THC, and SPREAD), by the CRISIS dummy, (2) we orthogonalize the resulting interaction terms by, to use one example, regressing the product term (ADVANCES $\mathrm{x}$ CRISIS) on a constant, ADVANCES, and CRISIS and keeping the residuals. The coefficients on the orthogonalized interaction terms may be viewed as pure interaction effects. The resulting orthogonalized interaction terms are denoted as: CRISIS*ADVANCES, CRISIS*NO_FHLB, CRISIS*THC, and CRISIS*SPREAD.

Following the literature, the SPREAD equation controls for the bond-issuing HC's features, bond features, and time effects. HC features include its market-value volatility $(V O L)$, size (the logarithm of the HCs' total assets, $S I Z E)$, return on assets $(R O A)$, and a binary indicator of the extent of its involvement in deposit-taking (DI_FOCUS, equals one for HCs with subsidiary total deposits greater than or equal to 25 percent of the HC's total assets, zero otherwise). We also control for factors such as bond liquidity, measured by the time since the bond was issued $(A G E)$, and the dollar amount of the bond issue at offering (ISSUE_SIZE), callability, putability, and junior status using binary variables $C A L L, P U T$, and SENIOR. The CRISIS binary equals one from Q3-2007 through Q1-2009 and zero otherwise. We include a number of other control variables following Merton (1974), Deng, Elyasiani, and Mao (2007), Elyasiani, Jia, and Mao 
(2010), and Yu (2005). These include market-value volatility (VOL ), equity capital ratio (LEVERAGE), and debt-to-value ratios (Merton, 1974). SIZE, is included because larger HCs may have more risk-reducing advantages such as the ability to obtain derivatives for hedging, hire skilled staff, and obtain high-cost, indivisible, technology. Return on assets (ROA) reflects profitability. DI_FOCUS is a binary variable set to zero if the $\mathrm{HC}$ is not primarily in the business of intermediation. ${ }^{7}$ Depending on the quarter, between one and fifteen of the HCs in the sample fall into this category. $A G E$ is included because bond liquidity risk may increase with time if the fraction of bond issues that settles into inactive portfolios increases with time. Bond ISSUE_SIZE is included because larger bond issues are better known to the investing public and, therefore, have lower liquidity risk. We include $C A L L$ because yields on bonds with call options are likely to be influenced by early payment risk. SENIOR debts are safer and earn lower yields. Inclusion of time variables is based on evidence in Collin-Dufresne et al. (2001) that much of the variation in bond prices is due to supply and demand factors specific to the bond market. Year-long, rather than quarterly, time dummy variables are used to maintain parsimony.

In the second equation, ADVANCES is modeled as a function of SPREAD; the CRISIS dummy, an interaction term between SPREAD and CRISIS; lagged ADVANCES and control variables. The coefficient on CRISIS*SPREAD shows the changes in the relationship between ADVANCES and SPREAD during the crisis. The control variables include the HCs' core deposits ratio (CORE), loans to deposits ratio (LD_RATIO), HC size (SIZE), the FHLB membership dummy (NO_FHLB), and the bond's time to maturity $(M A T)$. We include CORE because ADVANCES are substitutes for core deposits (Mays and DeMarco, 1989). Changes in LD_RATIO can affect an FI's liquidity position (Saunders and Cornett, 2010), thus influencing

\footnotetext{
${ }^{7}$ For example, the sample includes John Deere, an equipment manufacturer that operates an equipment financing unit that comprises a thrift.
} 
its demand for advances. We include SIZE because larger HCs have more potential funding sources and are more likely to complement $A D V A N C E S$ with other types of funds. We include NO_FHLB because HCs that do not control FHLB members cannot obtain advances. SPREAD is also known to vary with bonds' time to maturity (MAT). Finally, the crisis dummy accounts for the additional risk premia the markets may have assigned to bonds because of the uncertainties surrounding financial institutions during the crisis.

\section{Data Sources and Sample Selection}

\subsection{Variable Construction}

The methods used to calculate the model variables are summarized here and in Table 1. All data are quarterly. SPREAD is the median of the average daily yield spread, defined as the difference between yields on HC bonds and Treasury bonds with comparable maturities. The latter yields are calculated by interpolating the constant maturity Treasury yield curve for the day bond trades settle. ADVANCES are the aggregate FHLB advances of subsidiaries of a HC divided by HC's total liabilities. NO_FHLB equals one for HCs that do not control subsidiaries listed as FHLB members in the FHFA membership records, and zero otherwise. The THC dummy $(T H C)$ is set to one for HCs listed in the THC database of the Office of Thrift Supervision (OTS), zero otherwise. VOL, LEVERAGE, ROA, and SIZE are as defined earlier. $A G E$ is calculated by adding one to each bond's age (in years), then taking the logarithm to account for convexity in its relationship with SPREAD. ISSUE_SIZE is the logarithm of the dollar amount of the bonds' issue-size at offering. CALL, PUT, and SENIOR are set to one if the bond is callable, putable, or senior debt, respectively. CORE is the HCs' subsidiaries' total deposits minus brokered deposits divided by the HCs' total liabilities. The loan-deposit ratio 
( $\left.L D \_R A T I O\right)$ is the sum of the loans made by the subsidiaries of a HC, divided by their total deposits.

[Table 1 goes about here]

\subsection{Data Sources}

FINRA's TRACE database provides bond prices and trade dates. Constant maturity Treasury yields come from the Federal Reserve Board of Governors. The Mergent Fixed Income Security Database provides HC bond characteristics. HC-related data are from the Federal Reserve Bank of Chicago, the OTS, and Standard \& Poor's Compustat database. The Chicago Fed's call reports and the OTS-provided Thrift Financial Reports are the source for subsidiary data on banks and thrifts, respectively.

\subsection{Bond selection}

The FISD is the source for bond data. Bonds' characteristics were matched to financial statement data using the Committee on Uniform Security Identification Procedures (CUSIP) numbers. Bonds are excluded if they are convertible to stocks, denominated in foreign currency, carry variable rate coupons or coupons that are not semi-annual. Bonds issued by HCs that control FHLB member insurance companies are excluded because data are not available on the advances taken by insurance companies. HCs that are acquisition targets are excluded beginning with the quarter of the acquisition announcement. Finally, bonds traded fewer than five times in a quarter were removed to reduce the influence of outliers.

\section{Empirical Results}

This section contains descriptive statistics and estimation results on the relationship between cost of debt and FHLB advances as well as cost of debt and FHLB membership.

\subsection{Descriptive Statistics}


The sample includes 759 bonds issued by 53 HCs. The initial sample contains 9,321 observations from 27 quarters. Estimation is carried out on 8,223 observations over 26 quarters, because we include lagged dependent variables in the models. Panels A and B of Table 2 contain statistics on bond-specific and HC-specific variables, respectively. Table 3 presents the descriptive statistics for variables included in the regression models, including those presented in Table 2. The mean yield spread (SPREAD) is 34.2 basis points (bps). The mean bond offering amount (ISSUE_SIZE) is about $\$ 320$ million, with a minimum of $\$ 0.9$ million and a maximum of $\$ 5$ billion. About 94.5 percent of the observations are of bonds issued by HCs that control FHLB members. Advances to liability ratios (ADVANCES) range from zero to 35.81 percent, with a mean of 2.71 percent. About 23.1 percent of the observations are of THC bonds. The total assets of HCs range from $\$ 1.6$ billion to $\$ 2.3$ trillion with a mean of $\$ 1.1$ trillion and a median of about $\$ 1.3$ trillion. Most small BHCs and THCs do not issue bonds, so the sample is comprised of bonds issued by mid-size and large HCs. Bonds issued by large HCs comprise the majority of the observations. The conclusions based on this analysis may, therefore, not apply to small HCs. Though our sample does not represent a broad cross-section of the U.S. banking industry, it does represent a large portion of the total assets under control of BHCs and THCs. Because the OTS did not release financial statement data on THCs, we do not know what fraction of all HC assets our sample holds. However, Federal Reserve data indicate the sample's BHCs hold 60 to 70 percent of all U.S. BHC assets. Based on FHLB data, the HCs in the study held 25 to 35 percent of all FHLB advances outstanding, reflecting the tendency of small banks and thrifts to rely more on FHLBs for funding. [Tables 2 and 3 go about here]

\subsection{Multiple Regression Analysis: The OLS Results}

The model described by equations (1)-(2) is estimated using the ordinary least 
squares (OLS) and White's (1980) heteroskedastcity-robust standard errors. Results for the two equations are presented in Tables 4 and 5. The estimated coefficients measure the shortterm effects of the respective independent variables on the dependent variables. Long-term effects are calculated by dividing the short-run effects by $1-\lambda$, where $\lambda$ is the coefficient of the lagged dependent variable. The coefficient estimates for $\lambda$ on $S P R E A D_{t-1}$ are significant at the $1 \%$ level in all of the models, and the estimated magnitudes of $\lambda$ range from .672 to .674 , indicating the strength of the yield spread's dependence on its past values. The estimates for $\lambda$ on $A D V A N C E S_{t-1}$ indicate an even stronger dependence on past values, with the coefficients on 0.970 and statistical significance at the $1 \%$ level.

We describe the changes in a typical HC's cost of debt attributable to a one unit change in each factor using both the basis-point (bp) change in the yield spread and the change in the dollar value of the annual interest payment on the sample mean bond offering of $\$ 320$ million. We also measure the economic significance of $A D V A N C E S$ by using our model estimate to predict the effect on SPREAD of a relatively large increase in the HC's reliance on FHLB advances - an increase equivalent to one standard deviation in the ADVANCES sample, or $4.141 \%$. The effect of ADVANCES on SPREAD is defined as economically significant if such a change results in a long-term change in the annual interest payment of at least $1 \%$ of the mean bond issue-size $(\$ 3,200,000)$. Similarly, if a large, say 100 bps, change in SPREAD is associated with a long-term change in advances of at least 100 bps, we consider the effect to be economically significant.

\subsubsection{The SPREAD Equation (Equation (1))}

In the SPREAD equation, the coefficient of $A D V A N C E S$ is negative and significant at 
the $1 \%$ level (Table 4, Column 1), suggesting an inverse relationship between $\mathrm{HC}$ cost of debt and reliance on advances. This result supports hypothesis $\mathrm{H}_{1}$, indicating that increased advances are associated with a reduction in risk. FHLB members' success in obtaining advances at low cost appears to reduce the default risk for their bondholders, despite the 'super-lien' lender status of FHLBs, and sends a positive signal to the market about their credit-worthiness. This is similar to the 'certification effect' enjoyed by commercial firms when banks approve their requests for standby letters of credit, new loans, or loan renewals (James 1987; Billet, Flannery, and Garfinkel 1995). Moreover, borrowing from FHLBs curtails FHLB members' need to issue debt. If the supply curve for bonds is upward sloping, this reduces their average cost of bonds.

Our finding is consistent with the empirical findings of Scott and Hein (2011) but stands in contrast to the argument that FHLB advances lead to greater member risk (Nickerson and Phillips, 2004; Stojanovic, Vaughan, and Yeager 2008). Although banks can make risky loans using funds obtained through advances, risky loans are not the only way to profitably invest of these funds. Borrowing banks may choose to expand their loans in a responsible and profitable manner, especially when they know the FHLBs can take physical possession of their collateral and restrict their advances in future periods. If advances are conducive to greater bank risk, it seems that this effect is more than counterbalanced by the risk-reducing influences of FHLB policies and procedures.

In this model, the coefficient estimate for the interaction term between crisis and advances (CRISIS *ADVANCES) is statistically insignificant indicating lack of support for hypotheses $\mathrm{H}_{2}$. Reliance on advances appears not to exert additional downward pressure on the cost of debt during the crisis. This result may, however, be partially due to 
collinearity between advances and FHLB membership and/or another regressor in the model, or the single equation nature of the model which overlooks the possible endogeneity problem.

To investigate the collinearity issue, we take two steps. First, we orthogonalize the membership binary variable (NO_FHLB) against ADVANCES by regressing the former on the latter and a constant term, and using the residuals as an alternative regressor. The results based on this measure, reported in Table 4, Column 2, confirm the signs and significance of the corresponding coefficients reported in column 1 . This indicates that the effect of collinearity is not strong. Second, as an alternative way to avoid collinearity, we also re-estimate Equation (1), removing the membership binary variable $\left(N N_{-} F H L B\right)$ and the associated interaction term CRISIS*NO_FHLB. Results are reported in Table 4, Column 3. In this specification, the signs, significance and magnitudes of the coefficient of $A D V A N C E S$ remain unchanged, confirming our earlier result in support of hypothesis $\mathrm{H}_{1}$. However, the coefficient of the interaction term between crisis and advances does become significant at the $10 \%$ level, indicating that the effect of advances on the cost of debt did deepen during the crisis and that hypothesis $\mathrm{H}_{2}$ cannot be rejected. This is a reasonable finding because market participants value the FHLB support to its members to a greater extent when markets are in turmoil and liquidity is tight. This finding also provides some support for the argument that the correlation between advances and membership may have rendered the coefficient of the interaction term insignificant in the results reported in columns 1-2 of Table 4. In section 6.3, we employ the Three Stage Least Squares (3SLS) technique to address the possible endogeneity problem.

Hypotheses $\mathrm{H}_{3}$ and $\mathrm{H}_{4}$ suggest, respectively, that FHLB membership is associated with a lower cost of debt, beyond the effect exerted through advances, and that this effect strengthened 
during the crisis. However, the coefficient estimates for the membership binary variable $\left(N O_{-} F H L B\right)$ and its interaction term with the crisis binary $\left(C R I S I S * N O_{-} F H L B\right)$ are both found to be statistically insignificant (Table 4, Columns 1-2) indicating lack of support for these hypotheses. The insignificance of the coefficients on the membership dummy (NO_FHLB) and the corresponding interaction terms indicate that bond markets do not take FHLB membership alone as a sign of reduced (or increased) HC riskiness. This also indicates that the market gives more weight to the FHLB's judicial position in approving or denying of advances, than to membership in and of itself.

In terms of magnitude, the coefficient estimate for the variable $A D V A N C E S$ is -.022 (-2.2 bps) before the crisis and .031 during the crisis. The short-term effect of a one percentage point increase in the advances to liabilities ratio is a reduction of $2.2 \mathrm{bps}$ in the cost of debt prior to the crisis and $3.1 \mathrm{bps}$ during the crisis. These coefficient estimates imply a long-term effect on the yield spread of $6.8 \mathrm{bps}$ and $10 \mathrm{bps}$, respectively, for a one percentage point increase in the advances to liabilities ratio. Accordingly, the long-term economic impact, measured by the effect of a one standard deviation (4.141\%) change in $A D V A N C E S$ on the cost of debt is 28 bps in the pre-crisis period and $40 \mathrm{bps}$ during the crisis period, resulting in an interest saving of roughly $\$ 896,000$ and $\$ 1,325,120$, respectively, on the mean bond issue of $\$ 320$ million.

The coefficient estimate for the crisis dummy (CRISIS) is positive and significant in all three models and stands at 0.305 . This indicates that the risk premia on $\mathrm{HC}$ bonds increased by 30.5 bps during the crisis, in response to increased market volatility, tighter liquidity conditions, and bond buyers' elevated risk aversion. Risk premia show an autoregressive pattern as they are partially determined by their past values $\left(\mathrm{SPREAD}_{\mathrm{t}-1}\right)$. 
The coefficients of the THC binary variable (THC) and the interaction term CRISIS*THC are both positive and significant at the $1 \%$ and $5 \%$ levels, respectively. The magnitudes of these two coefficients stand at 0.470 (47.0 bps) and .083 (8.3 bps), respectively. This indicates that THC status is, ceteris paribus, associated with a greater cost of debt and, by implication, greater credit risk, compared to the BHCs. Based on these coefficient values, over the long-run, THC status is associated with an additional cost of debt of 143 bps before the crisis and 25.5 bps during the crisis. For the sample mean bond issue of $\$ 320$ million, the pre-crisis effects translate to an increase in the annual cost of debt of $\$ 1.5$ million over the short-run and $\$ 4.6$ million over the long-run, while the in-crisis effects add an additional cost of $\$ 266,000$ in the short-run and $\$ 816,000$ in the long-run to the figures for the pre-crisis period. The in-crisis figures are economically significant and greater than the magnitudes of the corresponding figures for a one standard deviation change in reliance on advances. This suggests that markets paid even more attention to HCs' regulators than HC's reliance on advances. One interpretation is that markets considered the THC regulator (the OTS) to be less effective in disciplining its subjects than the BHC regulator (the Fed). [Table 4 goes about here]

\subsubsection{The ADVANCES Equation (Equation 2)}

Results for the $A D V A N C E S$ equation are reported in Table 5. In this model the coefficient estimate for the cost of debt (SPREAD) is negative (-0.126) and significant at the $1 \%$ level, suggesting that greater cost of debt is associated with reduced levels of advances. This indicates that when a risky $\mathrm{HC}$ is disciplined by market participants, FHLBs also take complementary disciplinary action by restricting advances to it. This curtails the member's chances of making additional risky loans. Each FHLB charges the same interest rates on 
advances to all its members and, hence, its only disciplinary tools are to directly ration advances or toughen lending terms such as collateral and capital purchase requirements. In extreme cases, FHLBs may refuse to lend to banks which have little chance of redemption. ${ }^{8}$ This finding holds on average, but it may not be valid for every particular risky bank. FHLBs have the goal of stabilizing the mortgage market and may in particular cases relax their rationing of risky banks. This finding provides support for hypothesis $\mathrm{H}_{5}$.

\section{[Table 5 goes about here]}

Advances' sensitivity to cost of debt is found to increase during the crisis as the coefficient of the interaction term CRISIS* SPREAD is negative (-0.240) and significant at the $1 \%$ level. In other words, as HCs become riskier during the crisis, the level of advances they can utilize will be, on average, subject to greater restrictions than under ordinary economic conditions. This result supports hypothesis $\mathrm{H}_{6}$ and is consistent with Scott and Hein's $(2011,2009)$ argument that as riskiness of FHLB members rises, FHLBs require them to purchase additional FHLB capital, take possession of their collateral, or both.

In economic terms, a $100 \mathrm{bp}$ increase in cost of debt (risk) is associated with a shortterm 12.6 bp reduction in $A D V A N C E S$ before the crisis and an additional 24 bp reduction during the crisis, demonstrating a near-tripling of the effect (36.7 bp) in the latter period. Considering that the sample mean of $A D V A N C E S$ is $2.72 \%$ of liabilities, a 100 bps increase in yield spread on $\mathrm{HCs}$ ' unsecured debt translates into a reduction of the mean to $2.59 \%$ during the pre-crisis period and to $2.35 \%$ during the crisis period. The long-term effects of a $100 \mathrm{bps}$ increase in yield spread on advances are much higher; $4.15 \%$ before the crisis and an additional $7.87 \%$ during the crisis. With these sharp effects, FHLBs are likely to cease to provide advances to

\footnotetext{
${ }^{8}$ If a member FI is perceived to be beyond redemption, the FHLB may deny advances. Unfortunately, no data on cases of denial of advances are publicly available. These cases are kept strictly confidential.
} 
many of the HCs before a new long-term equilibrium is reached. A note of caution, however, is that the coefficients on cost of debt may encompass some reverse causality effects, reflecting the effect of advances on the cost of debt. If so, the cost of debt's effect on advances may be overestimated. This possibility will be accounted for in the next section with 3SLS estimation of a system model.

Among the control variables, the CRISIS dummy produces a shift upward in the level of advances, as it has a positive coefficient. This is to be expected as demand for advances grows during the times of crises, and one purpose of the FHLBs is to satisfy heightened demand during liquidity shortages. However, the negative coefficient of the interaction of CRISIS and SPREAD indicates that for riskier FHLB members, advances increased more slowly during the crisis than for safer members. 2SLSThe coefficients for CORE and LD_RATIO are both positive, suggesting that FHLB members with greater shares of core deposit in their liabilities, and greater loan to deposit ratios, take greater amounts of advances from the FHLBs. These findings are reasonable because deposits are highly volatile and higher loan to deposit ratios correspond to tighter liquidity conditions. Advances are also found to be highly autoregressive, suggesting that FHLB members taking advances continue to do so over time. The lagged ADVANCES coefficient is 0.97 meaning that as much as $97 \%$ of advances in each period were determined by their previous-period values.

\subsection{Model Extensions and Robustness Checks}

In this section, we report the results of an alternative estimation technique and several new model specifications. The OLS estimation results show that higher values of $A D V A N C E S$ are associated with lower costs of debt (SPREAD), and, conversely, higher values of SPREAD are associated with lower $A D V A N C E S$. In other words, the two variables are jointly determined. 
The coefficient on $A D V A N C E S$ in equation (1) and the coefficient on SPREAD in equation (2) may, therefore, suffer from endogeneity bias. To address this concern, we estimate our twoequation system using the 3SLS technique. This technique allows for contemporaneous correlations between the disturbances in the two equations and generates simultaneous twostage least squares estimates for each equation in the system. Given the simultaneity in the relationship between SPREAD and ADVANCES, the 3SLS results, displayed in Table 6 are deemed more reliable than the OLS results.

The 3SLS coefficient estimates for the variables of interest have the same signs as OLS estimates, and their statistical significance is also sustained at conventional levels. The coefficients for $A D V A N C E S$ and the interaction term $C R I S I S^{*} A D V A N C E S$ in equation (1) remain negative, providing support for hypotheses $\mathrm{H}_{1}$ and $\mathrm{H}_{2}$, which purport a negative relationship between advances and cost of debt before the crisis that strengthens during the crisis. The latter result is an improvement over our OLS-based finding that suggested no effect from the crisis and supported rejection of $\mathrm{H}_{2}$. The SPREAD and the interaction term (SPREAD*CRISIS) coefficients in equation (2) remain negative, indicating that FHLBs restrict advances to riskier members, more so during the crisis. This estimated effect under 3SLS is stronger than under OLS. These results establish the robustness of our finding regarding $\mathrm{H}_{1}$ to the 3SLS procedure, with the additional finding that $\mathrm{H}_{2}$ is supported with the more reliable 3SLS procedure.

Several alternative model specifications are also used to check the robustness of our findings. If the supply-curve for bonds slopes upward, HCs that fund their operations with bonds to a larger extent would pay greater yields on their bonds and incur a higher average cost of debt. A counterbalancing effect, however, is that greater reliance on bonds may send a positive signal to 
the market about the HC's credit and lower its cost of debt. The HC would also demonstrate independence from advances and willingness to subject itself to market discipline. To account for these countervailing effects, we extend our model to include $B O N D S$, defined as bonds to liabilities ratio, as a regressor in the $S P R E A D$ equation. We estimate the augmented model using the 3SLS procedure.

[Table 6 goes about here]

The signs and significance of the coefficients of the variables of interest (Table 6) remain the same while the coefficient of $B O N D S$ is statistically insignificant. To ensure that the leverage effect does not play a role, we also estimate the model, adding leverage ( $L E V E R A G E)$, as an additional regressor. Results based on this extended model also show the coefficient of $B O N D S$ to be statistically insignificant, confirming our earlier result. As a further check, we also estimate the model with the logarithm of each HC's total bonds outstanding $\left(L O G_{-} T B O\right)$, instead of $B O N D S$ as well as $L O G_{-} T B O$ and $L E V E R A G E$. The coefficient on $L O G \_T B O$ is insignificant in both models. We find that HCs' reliance on bonds impacts neither the results nor our conclusions in regards to reliance on advances.

\section{Conclusion}

Previous research has produced conflicting conclusions regarding the relationship between FI cost of debt and reliance on FHLB advances. Theoretically, some argue that a positive relationship can be expected because FHLB managers lack sufficient incentives to monitor their members' risk and because interest rates on advances are not risk-based. Others argue the opposite on the grounds that FHLBs curtail advances to risky members, raise their collateral and capital purchase requirements to increase their cost of advances, and offer risk management resources to members, some of which might not have access to such resources. We examine the issue using yield spreads on $\mathrm{HC}$ bonds to measure $\mathrm{HC}$ risk and advances to 
liabilities ratios to measure HC reliance on advances. Yield spreads is a market-based, rather than accounting-based, risk measure, and it is being used for this purpose for the first time in an FHLB study. Single-equation and system-based techniques are both used to estimate the models.

Our results indicate that higher reliance on advances is associated with lower, rather than higher, cost of debt, prior to the financial crisis, with the association strengthening during the crisis. On the other hand, changes in cost of debt are found to have a statistically and economically significant negative effect on advances to liability ratio before and during the crisis. This finding indicates FHLBs curtail advances to riskier members by rationing, raising collateral requirements, or both. This effect strengthens during the crisis. It is notable that this effect may not operate in each HC's case, as FHLBs may choose to help some risky banks in distress, but it does hold true on average. Furthermore, we find that FHLB membership, independent of advance taking, has an insignificant effect on cost of debt throughout the period studied, even though it entitles members to benefits other than advance taking such as risk management resources and emergency funding during credit crunches. Relative to BHCs, the cost of debt for THCs is greater by a significant margin and this gap widens during the crisis as the risk premia on riskier loans increase with market turbulence and increased uncertainty.

Our findings imply that FHLB policies toward advances do more to discourage risky lending than to encourage it. For policy makers, these results suggest that FHLB advances support homeownership without adding to the FHLB members' risk or to the financial system risk. They also provide evidence that FHLB advances are a back-up funding source for relatively low-risk banks and thrifts in both ordinary times and credit crunches, though the process limits availability to riskier borrowers, further stiffening the rate they have to pay in the market for funds. The overall effect on systemic risk is unclear. As calls for the elimination of Fannie Mae 
and Freddie Mac increase, Congress and the President should consider the performance of the FHLBs separately from other housing Government-Sponsored-Enterprises. For BHC and THC managers, the results imply that reliance on FHLB advances entails a beneficial signaling or certification effect as it calms the concerns of private market providers of funds. The results showing that THCs pay a greater rate on their debt than BHCs and that the gap widened during the crisis, provides some support for the decision to eliminate the office of thrift supervision (OTS) because it seems that OTC was less effective in disciplining its members in terms of risk taking. As a note of caution, since the sample includes primarily mid-sized and large BHCs and THCs, our results should be applied to small HCs with caution.

\section{Acknowledgments}

We thank the following for useful comments and suggestions that were incorporated into the paper: Andrew Economopoulos, Scott Frame, Yan Li, Iqbal Mansur, Jonathan Scott, Larry Wall, Timothy Yeager, Hakan Yilmazkuday, faculty and students in the Temple University Economics Department dissertation seminar, officers of the Federal Home Loan Banks of Pittsburgh and Dallas, the staff of the Federal Housing Finance Agency, and an anonymous referee of this journal. We are also grateful to Gary Ternullo of the Federal Housing Finance Agency for providing FHLB membership data and to Jim Caton and Keith Lester of the OTS for providing thrift and THC data. The second author is also a Fellow at the Wharton Financial Institution Center and a visiting professor and Dean's Fellow at the Hebrew University, Jerusalem. He would like to thank Temple University for Summer Research Grants 2013 and 2014. All errors are ours. 


\section{References}

Ambrose, B. W., and A. Warga. 2002. Measuring potential GSE funding advantages. The Journal of Real Estate Finance and Economics 25 (2): 129-150.

Ashcraft, A., M. L. Bech, and W. S. Frame. 2010. The Federal Home Loan Bank System: The Lender of Next-to-Last Resort? Journal of Money, Credit, and Banking 42 (4): 551-583.

Ashley, L. K., E. Brewer, and N. E. Vincent. 1998. Access to FHLBank advances and the performance of thrift institutions. Economic Perspectives (Federal Reserve Bank of Chicago) 22 (2): 33.

Billett, M. T., M. J. Flannery, and J. A. Garfinkel. 1995. The Effect of Lender Identity on a Borrowing Firm's Equity Return. Journal of Finance 50 (2): 699-718.

Bhojraj, S., and P. Sengupta. 2003. Effect of corporate governance on bond ratings and yields: The role of institutional investors and outside directors. Journal of Business 76 (3): 455-475.

Che, Y. 2002. Joint liability and peer monitoring under group lending. Contributions to Theoretical Economics 2 (1): 1016.

Collin-Dufresne, P., R. S. Goldstein, and J. S. Martin. 2001. The determinants of credit spread changes. Journal of Finance 56 (6): 2177-2207.

Deng, S., E. Elyasiani, and C. X. Mao. 2007. Diversification and the cost of debt of bank holding companies. Journal of Banking and Finance 31 (8): 2453-2473.

Deng, S., E. Elyasiani, and C. X. Mao. 2013. BHC Derivatives Usage, Cost of Debt and Lending Patterns. Working paper, Temple University.

Elyasiani, E., J. Jia, and C. X. Mao. 2010. Institutional ownership stability and cost of debt financing. Journal of Financial Markets 13 (4): 475-500.

Flannery, M. J., and W. S. Frame. 2006. The Federal Home Loan Bank system: The "other" housing GSE. Federal Reserve Bank of Atlanta Economic Review 91 (3): 33-54.

Ghatak, M., and T. W. Guinnane. 1999. The economics of lending with joint liability: Theory and practice. Journal of Development Economics 60 (1): 195-228.

Gorton, G. 2010. Questions and answers about the financial crisis. NBER Working Paper Series, (15787)

Hoffmann, S. 2001. Politics and Banking: Ideas, Public Policy, and the Creation of Financial Institutions. Baltimore: Johns Hopkins University Press.

Jagtiani, J. and C. Lemieux. 2001. Market discipline prior to bank failure. Journal of Economics and Business 53 (2-3): 313-324.

James, C. 1987. Some Evidence on the Uniqueness of Bank Loans. Journal of Financial Economics 19 (2): 217-235.

Kim, Y., H. Li, and S. Li. 2012. Does eliminating the Form 20-F reconciliation from IFRS to U.S. GAAP have capital market consequences? Journal of Accounting and Economics 53 (1-2): 249-270.

King, T. D., and K. Khang. 2005. On the importance of systematic risk factors in explaining the cross-section of corporate bond yield spreads. Journal of Banking and Finance 29 (12): 3141-3158.

Klock, M. S., S. A. Mansi., and F. W. Maxwell. 2005. Does corporate governance matter to bondholders? Journal of Financial and Quantitative Analysis 40 (4): 693. 
Mays, E., and E. J. DeMarco. 1989. The demand for Federal Home Loan Bank advances by thrift institutions: Some recent evidence. Journal of the American Real Estate and Urban Economics Association 17 (3): 363-379.

Merton, R. C. 1974. On the pricing of corporate debt: The risk structure of interest rates. Journal of Finance 29 (2): 449-470.

Mishkin, F. 2011. Over the cliff: From the subprime to the global financial crisis. Journal of Economic Perspectives 25 (1): 49-70.

Nickerson, D., and R. J. Phillips. 2004. "The Federal Home Loan Bank system and the farm credit system: Parallels and implications for systemic risk." In Too big to fail: Policies and practices in government bailouts, edited by B. E. Gup, Westport, CT: Praeger.

Nothaft, F. E., J. E. Pearce, and S. Stevanovic. 2002. Debt spreads between GSEs and other corporations. The Journal of Real Estate Finance and Economics 25 (2): 151-172.

Sarig, O., and A. Warga. 1989. Bond price data and bond market liquidity. Journal of Financial and Quantitative Analysis 24 (3): 367-378.

Saunders, A., and M. M. Cornett. 2010. Financial institutions management: A risk management approach. 7th ed. New York: McGraw Hill.

Scott, J. A., and S. E. Hein. 2011. The Federal Home Loan Bank system: A government sponsored enterprise that avoided conservatorship. Journal of Applied Finance 21 (1): 4461.

Scott, J. A., and S. E. Hein. 2009. The Federal Home Loan Banks and commercial bank risk taking: An overstated moral hazard? Working Paper - Temple University.

Stiglitz, J. E. 1990. Peer monitoring and credit markets. The World Bank Economic Review 4 (3): 351-366.

Stojanovic, D., M. D. Vaughan, and T. J. Yeager. 2008. Do Federal Home Loan Bank membership and advances increase bank risk-taking? Journal of Banking and Finance 32 (5): 680-698.

White, H. 1980. A heteroskedasticity-consistent covariance matrix estimator and a direct test for heteroskedasticity. Econometrica 48 (4): 817-838.

$\mathrm{Yu}, \mathrm{F} .2005$. Accounting transparency and the term structure of credit spreads. Journal of

Financial Economics 75 (1): 53-84. 


\section{Table 1. Variable descriptions}

\begin{tabular}{|c|c|}
\hline Variable & Description \\
\hline$A D V A N C E S$ & HC ratio of advances to total liabilities, in percent. \\
\hline$A G E$ & $\begin{array}{l}\text { Age of the bond in years. For regression model estimates, transformed by adding } \\
\text { one to the bond's age in years, then taking the logarithm. }\end{array}$ \\
\hline$C A L L$ & Dummy variable; one if the bond is callable, zero otherwise. \\
\hline CORE & $\mathrm{HC}$ ratio of core deposits to total liabilities, in percent. \\
\hline CRISIS & Dummy variable; one from Q3-2007 to Q1-2009, zero otherwise. \\
\hline CRISIS*ADVANCES & $\begin{array}{l}\text { Orthogonalized interaction of crisis dummy (Q3-2007 to Q1-2009) and } \\
\text { ADVANCES. }\end{array}$ \\
\hline CRISIS*NO_FHLB & $\begin{array}{l}\text { Orthogonalized interaction of crisis dummy (Q3-2007 to Q1-2009) and FHLB } \\
\text { membership dummy. }\end{array}$ \\
\hline CRISIS*SPREAD & $\begin{array}{l}\text { Orthogonalized interaction of crisis dummy (Q3-2007 to Q1-2009) and } \\
\text { SPREAD. }\end{array}$ \\
\hline CRISIS*THC & $\begin{array}{l}\text { Orthogonalized interaction of crisis dummy (Q3-2007 to Q1-2009) and THC } \\
\text { dummy. }\end{array}$ \\
\hline DI_FOCUS & $\begin{array}{l}\text { Dummy variable, one for } \mathrm{HCs} \text { with total deposits at subsidiaries greater } \\
\text { than or equal to } 25 \text { percent of } \mathrm{HC} \text { total assets. }\end{array}$ \\
\hline ISSUE_SIZE & $\begin{array}{l}\text { Bond's issue size, in thousands of dollars. The logarithm is used in regression } \\
\text { model estimates. }\end{array}$ \\
\hline LD_RATIO & HC's ratio of total loans to total deposits, in percent. \\
\hline$M A T$ & Bond's time to maturity, in years. \\
\hline NO_FHLB & $\begin{array}{l}\text { Dummy variable; one if the HC does not control an FHLB member subsidiary, } \\
\text { zero otherwise. }\end{array}$ \\
\hline$P U T$ & Dummy variable; one if the bond is putable, zero otherwise. \\
\hline$R O A$ & HC's ratio of net income with extraordinary items to total assets, in percent. \\
\hline SENIOR & Binary variable; one if the bond is a senior debt, zero otherwise. \\
\hline SIZE & $\begin{array}{l}\text { HC total assets in thousands of dollars. The logarithm is used in regression } \\
\text { model estimates. }\end{array}$ \\
\hline$S P R E A D$ & Quarterly median daily average yield spreads. \\
\hline$T H C$ & Binary variable; one for THCs, zero otherwise. \\
\hline$V O L$ & Standard deviation of the HC's stock return. \\
\hline
\end{tabular}


Table 2. Descriptive statistics

\begin{tabular}{lrrrlll}
\hline Variables & $\mathrm{N}$ & Mean & SD & Median & Min & Max \\
\hline Panel A: Bond-specific variables & & & & & & \\
\hline AGE (years) & 8,223 & 3.912 & 2.976 & 3.35 & 0.106 & 19.92 \\
CALL (binary) & 8,223 & 0.536 & 0.499 & 1 & 0 & 1 \\
ISSUE_SIZE (\$millions) & 8,223 & 319.8 & 608.7 & 29.02 & 900 & 5,000 \\
MAT (years) & 8,223 & 11.12 & 8.001 & 8.833 & 0 & 34.99 \\
PUT (binary) & 8,223 & 0.013 & 0.115 & 1 & 0 & 1 \\
SENIOR (binary) & 8,223 & 0.394 & 0.489 & 0 & 0 & 1 \\
SPREAD (percentage points) & 8,223 & 0.342 & 1.305 & 0.140 & -4.900 & 8.555 \\
Number of bonds in sample & 759 & & & & & \\
& & & & & & \\
Panel B: HC-specific variables & & & & & \\
ADVANCES & 8,223 & 2.717 & 4.141 & 1.934 & 0 & 35.81 \\
CORE (\%) & 8,223 & 39.37 & 20.49 & 44.64 & 0 & 1 \\
DI_FOCUS (binary) & 8,223 & 0.801 & 0.399 & 1 & 0 & 1 \\
NO_FHLB (binary) & 8,223 & 0.055 & 0.228 & 0 & 0 & 1274 \\
LD_RATIO (\%) & 8,223 & 109.4 & 61.56 & 110.6 & 0 & 2.384 \\
ROA (\%) & 8,223 & 0.308 & 0.575 & 0.306 & -7.166 & 1 \\
SIZE (\$billions) & 8,223 & 1,060 & 685.9 & 1,256 & 1,638 & 0.206 \\
THC (binary) & 8,223 & 0.231 & 0.421 & 0 & 0 & \\
VOL & 8,223 & 0.026 & 0.033 & 0.012 & 0.005 & \\
Number of HCs in sample & 53 & & & & &
\end{tabular}

Variables are defined in Table 1. 
Table 3. Descriptive statistics

\begin{tabular}{|c|c|c|c|c|c|c|}
\hline Variables & $\mathrm{N}$ & Mean & $\mathrm{SD}$ & Median & Min & Max \\
\hline$A D V A N C E S$ & 8,223 & 2.717 & 4.141 & 1.934 & 0 & 35.81 \\
\hline$A G E$ (years) & 8,223 & 3.912 & 2.976 & 3.35 & 0.106 & 19.92 \\
\hline$C A L L$ (binary) & 8,223 & 0.536 & 0.499 & 1 & 0 & 1 \\
\hline CORE $(\%)$ & 8,223 & 39.37 & 20.49 & 44.64 & 0 & 93.28 \\
\hline CRISIS & 8,223 & 0.366 & 0.482 & 0 & 0 & 1 \\
\hline CRISIS*ADVANCES & 8,223 & 1.128 & 2.383 & 0 & 0 & 27.564 \\
\hline CRISIS*SPREAD & 8,223 & 0.391 & 0.951 & 0 & -4.040 & 8.555 \\
\hline CRISIS*THC & 8,223 & 0.072 & 0.258 & 0 & 0 & 1 \\
\hline DI_FOCUS (binary) & 8,223 & 0.801 & 0.399 & 1 & 0 & 1 \\
\hline$I S \overline{S U} U E \_S I Z E$ (\$millions) & 8,223 & 319.8 & 608.7 & 29.02 & 900 & 5,000 \\
\hline LDRATIO (\%) & 8,223 & 109.4 & 61.56 & 110.6 & 0 & 1274 \\
\hline$M A T$ (years) & 8,223 & 11.12 & 8.001 & 8.833 & 0 & 34.99 \\
\hline$N O \_F H L B$ (binary) & 8,223 & 0.055 & 0.228 & 0 & 0 & 1 \\
\hline$P U \bar{T}$ (binary) & 8,223 & 0.013 & 0.115 & 1 & 0 & 1 \\
\hline$R O A(\%)$ & 8,223 & 0.308 & 0.575 & 0.306 & -7.166 & 5.384 \\
\hline SENIOR (binary) & 8,223 & 0.394 & 0.489 & 0 & 0 & 1 \\
\hline SIZE (\$billions) & 8,223 & 1,060 & 685.9 & 1,256 & 1,638 & 2,323 \\
\hline SPREAD (percentage points) & 8,223 & 0.342 & 1.305 & 0.140 & -4.900 & 8.555 \\
\hline$T H C$ (binary) & 8,223 & 0.231 & 0.421 & 0 & 0 & 1 \\
\hline$V O L$ & 8,223 & 0.026 & 0.033 & 0.012 & 0.005 & 0.206 \\
\hline
\end{tabular}

Variables are defined in Table 1. 
Table 4. The SPREAD equation (equation 1)- OLS estimates

\begin{tabular}{|c|c|c|c|c|}
\hline & $\begin{array}{l}\text { OLS - Initial } \\
\text { Specification } \\
\text { (1) }\end{array}$ & $\begin{array}{l}\text { OLS - Second } \\
\text { Specification } \\
(2) \\
\end{array}$ & $\begin{array}{l}\text { OLS - Third } \\
\text { Specification } \\
(3)\end{array}$ & $\begin{array}{l}\text { Long-Run Effect } \\
\text { OLS - Third Specification } \\
\text { (4) }\end{array}$ \\
\hline$A D V A N C E S$ & $\begin{array}{l}-0.022 * * * \\
(0.004)\end{array}$ & $\begin{array}{l}-0.022^{* * *} \\
(0.004)\end{array}$ & $\begin{array}{l}-0.022 * * * \\
(0.004)\end{array}$ & -0.068 \\
\hline CRISIS*ADVANCES & $\begin{array}{l}-0.009 \\
(0.006)\end{array}$ & $\begin{array}{l}-0.009 \\
(0.006)\end{array}$ & $\begin{array}{l}-0.009 * \\
(0.005)\end{array}$ & -0.028 \\
\hline$N O \_F H L B$ & $\begin{array}{l}0.030 \\
(0.041)\end{array}$ & $\begin{array}{l}0.030 \\
(0.041)\end{array}$ & & \\
\hline CRISIS*NO_FHLB & $\begin{array}{l}0.004 \\
(0.089)\end{array}$ & $\begin{array}{l}-0.004 \\
(0.090)\end{array}$ & & \\
\hline THC & $\begin{array}{l}0.469 * * * \\
(0.087)\end{array}$ & $\begin{array}{l}0.469 * * * \\
(0.087)\end{array}$ & $\begin{array}{l}0.470 * * * \\
(0.087)\end{array}$ & 1.430 \\
\hline CRISIS*THC & $\begin{array}{l}0.085^{*} \\
(0.048)\end{array}$ & $\begin{array}{l}0.085^{*} \\
(0.048)\end{array}$ & $\begin{array}{l}0.084 * \\
(0.045)\end{array}$ & 0.255 \\
\hline$V O L$ & $\begin{array}{l}9.005^{* * *} \\
(0.467)\end{array}$ & $\begin{array}{l}9.000 * * * \\
(0.467)\end{array}$ & $\begin{array}{l}9.014 * * * \\
(0.466)\end{array}$ & 27.500 \\
\hline$R O A$ & $\begin{array}{l}-0.086^{* * * *} \\
(0.027)\end{array}$ & $\begin{array}{l}-0.086^{* * *} \\
(0.027)\end{array}$ & $\begin{array}{l}-0.084 * * * \\
(0.027)\end{array}$ & -0.255 \\
\hline SIZE & $\begin{array}{l}-0.052 * * * \\
(0.009)\end{array}$ & $\begin{array}{l}-0.052 * * * \\
(0.009)\end{array}$ & $\begin{array}{l}-0.054 * * * \\
(0.009)\end{array}$ & -0.164 \\
\hline DI_FOCUS & $\begin{array}{l}0.467 * * * \\
(0.102)\end{array}$ & $\begin{array}{l}0.468 * * * \\
(0.102)\end{array}$ & $\begin{array}{l}0.466 * * * \\
(0.101)\end{array}$ & 1.420 \\
\hline$A G E$ & $\begin{array}{l}0.162 * * * \\
(0.019)\end{array}$ & $\begin{array}{l}0.162 * * * \\
(0.019)\end{array}$ & $\begin{array}{l}0.161 * * * \\
(0.019)\end{array}$ & 0.491 \\
\hline ISSUE_SIZE & $\begin{array}{l}-0.038^{* * *} \\
(0.006)\end{array}$ & $\begin{array}{l}0.038 * * * \\
(0.006)\end{array}$ & $\begin{array}{l}0.038 * * * \\
(0.006)\end{array}$ & 0.117 \\
\hline$C A L L$ & $\begin{array}{l}0.004 \\
(0.021)\end{array}$ & $\begin{array}{l}0.004 \\
(0.021)\end{array}$ & $\begin{array}{l}0.004 \\
(0.021)\end{array}$ & 0.011 \\
\hline PUT & $\begin{array}{l}-0.34 * * * \\
(0.067)\end{array}$ & $\begin{array}{l}-0.314 * * * \\
(0.067)\end{array}$ & $\begin{array}{l}-0.312 * * * \\
(0.067)\end{array}$ & -0.950 \\
\hline SENIOR & $\begin{array}{l}-0.272 * * * \\
(0.028)\end{array}$ & $\begin{array}{l}-0.272 * * * \\
(0.028)\end{array}$ & $\begin{array}{l}-0.273 * * * \\
(0.028)\end{array}$ & -0.832 \\
\hline CRISIS & $\begin{array}{l}0.305 * * * \\
(0.024)\end{array}$ & $\begin{array}{l}0.305^{* * *} \\
(0.024)\end{array}$ & $\begin{array}{l}0.306 * * * \\
(0.024)\end{array}$ & 0.932 \\
\hline$S P R E A D_{t-1}$ & $\begin{array}{l}0.672 * * * \\
(0.010)\end{array}$ & $\begin{array}{l}0.672 * * * \\
(0.010)\end{array}$ & $\begin{array}{l}0.672 * * * \\
(0.010)\end{array}$ & \\
\hline INTERCEPT & $\begin{array}{l}-0.047 \\
(0.230)\end{array}$ & $\begin{array}{l}-0.044 \\
(0.229)\end{array}$ & $\begin{array}{l}-0.016 \\
(0.227)\end{array}$ & \\
\hline $\begin{array}{l}\text { Number of observations } \\
R^{2}\end{array}$ & $\begin{array}{l}8,223 \\
0.702\end{array}$ & $\begin{array}{l}8,223 \\
0.702\end{array}$ & $\begin{array}{l}8,223 \\
0.702\end{array}$ & \\
\hline
\end{tabular}

Note: Columns 1-3 contain the coefficient estimates, respectively, for the baseline model (Eq. 1), the model using the orthogonalized values of $N O \_F H L B$ and $C R I S I{ }^{*} N O_{-} F H L B$ variables and the model excluding $N O \_F H L B$ and CRISIS*NO_FHLB (see Section 3). White's (1980) standard errors are in parentheses Coefficient estimates are the short-run effects. Column 4 contains long-run effects for the final specification (the short-run effects divided by the adjustment term; 1the coefficient of SPREAD $D_{t-1}$ ). Variables definitions are as in Table 1, except for SIZE, AGE, and ISSUE_SIZE. SIZE is the logarithm of total assets in thousands of dollars, $A G E$ is calculated by adding 1 to the bond's age in years then taking the logarithm. ISSUE_SIZE is the logarithm of the bond's issue size in thousands of dollars. *,**, and *** indicate statistical significances at the $10 \%, 5 \%$, and $1 \%$ level, respectively. 
Table 5. The ADVANCES Equation (Equation 2)- The OLS Estimates

\begin{tabular}{|c|c|c|c|c|}
\hline & $\begin{array}{l}\text { OLS } \\
\text { (1) }\end{array}$ & $\begin{array}{l}\text { 3SLS } \\
\text { (2) }\end{array}$ & $\begin{array}{c}\text { Long-run effect } \\
\text { (OLS) } \\
\text { (3) }\end{array}$ & $\begin{array}{c}\text { Long-run effect (3SLS) } \\
\text { (4) }\end{array}$ \\
\hline SPREAD & $\begin{array}{l}-0.126^{* * * *} \\
(0.010)\end{array}$ & $\begin{array}{l}-0.144^{* * *} \\
(0.009)\end{array}$ & -4.150 & -4.733 \\
\hline CRISIS*SPREAD & $\begin{array}{l}-0.240 * * * \\
(0.018)\end{array}$ & $\begin{array}{l}-0.235^{* * *} \\
(0.014)\end{array}$ & -7.870 & -7.740 \\
\hline CORE $\left(\times 10^{-3}\right)$ & $\begin{array}{l}1.701 * * * \\
(0.563)\end{array}$ & $\begin{array}{l}1.694 * * * \\
(0.490)\end{array}$ & 0.056 & 55.814 \\
\hline$L D \_R A T I O\left(\times 10^{-3}\right)$ & $\begin{array}{l}0.375 * * * \\
(0.059)\end{array}$ & $\begin{array}{l}0.366^{* *} \\
(0.015)\end{array}$ & 0.012 & 12.052 \\
\hline SIZE & $\begin{array}{l}-0.020 * * * \\
(0.008)\end{array}$ & $\begin{array}{l}-0.022 * * * \\
(0.007)\end{array}$ & -0.645 & -0.723 \\
\hline$N O \_F H L B$ & $\begin{array}{l}-0.139 * * * \\
(0.019)\end{array}$ & $\begin{array}{l}-0.140^{* * *} \\
(0.045)\end{array}$ & -4.570 & -4.623 \\
\hline$M A T$ & $\begin{array}{l}-0.002 * * \\
(0.001)\end{array}$ & $\begin{array}{l}-0.002 * \\
(0.001)\end{array}$ & -0.058 & -0.061 \\
\hline CRISIS & $\begin{array}{l}0.105^{* * *} \\
(0.024)\end{array}$ & $\begin{array}{l}0.127 * * * \\
(0.021)\end{array}$ & 3.440 & 3.854 \\
\hline$A D V A N C E S_{t-1}$ & $\begin{array}{l}0.970 * * * \\
(0.006)\end{array}$ & $\begin{array}{l}0.970 * * * \\
(0.002)\end{array}$ & & \\
\hline INTERCEPT & $\begin{array}{l}0.436 * * * \\
(0.156)\end{array}$ & $\begin{array}{l}0.481 * * * \\
(0.133)\end{array}$ & 14.300 & \\
\hline $\begin{array}{l}\text { Number of observations } \\
R^{2}\end{array}$ & $\begin{array}{l}8,223 \\
0.966 \\
\end{array}$ & $\begin{array}{l}8,223 \\
0.976 \\
\end{array}$ & & \\
\hline \multicolumn{5}{|c|}{$\begin{array}{l}\text { Note: This table reports the estimation results for the regression model describing the advances to liabilities ratio } \\
(A D V A N C E S \text { ). Columns } 1-2 \text { contain the coefficient estimates for the baseline model (Eq. } 2 \text { ) using the OLS and the } \\
\text { 3SLS, respectively (see Section 3). White's (1980) standard errors are in parentheses. Coefficient estimates are the } \\
\text { short-run effects. Columns 3-4 contain the long-run effects (the short-run effects divided by the adjustment term; } 1- \\
\text { the coefficient of } S P R E A D_{t-1} \text { ). Variable definitions are as in Table } 1 \text {, except for } S I Z E \text {, which is the logarithm of total } \\
\text { assets in thousands of dollars. *,**, and *** indicate statistical significances at the } 10 \%, 5 \% \text {, and } 1 \% \text { level, } \\
\text { respectively. }\end{array}$} \\
\hline
\end{tabular}


Table 6: The SPREAD Equation - Alternative Specifications and Estimation Methods

\begin{tabular}{|c|c|c|c|c|c|c|}
\hline & $\begin{array}{l}\text { OLS } \\
\text { (BONDS) } \\
\text { (1) }\end{array}$ & $\begin{array}{l}\text { OLS } \\
(B O N D S \text { and } \\
L E V E R A G E) \\
(2)\end{array}$ & $\begin{array}{l}\text { OLS } \\
\left(L O G \_T B O\right) \\
(3)\end{array}$ & $\begin{array}{l}\text { OLS } \\
\left(L O G_{-} T B O\right. \\
\text { and } \\
L E V E R A G E) \\
\text { (4) }\end{array}$ & $\begin{array}{l}\text { 3SLS } \\
\text { (Final } \\
\text { Specification) } \\
\text { (5) }\end{array}$ & $\begin{array}{l}\text { Long-Run } \\
\text { Effect - } \\
\text { 3SLS } \\
(6)\end{array}$ \\
\hline$A D V A N C E S$ & $\begin{array}{l}-0.022 * * * \\
(0.004)\end{array}$ & $\begin{array}{l}-0.015 * * * \\
(0.004)\end{array}$ & $\begin{array}{l}-0.022 * * * \\
(0.004)\end{array}$ & $\begin{array}{l}-0.015 * * * \\
(0.004)\end{array}$ & $\begin{array}{l}-0.011 * * * \\
(0.04)\end{array}$ & -0.034 \\
\hline CRISIS*ADVANCES & $\begin{array}{l}-0.009 \\
(0.006)\end{array}$ & $\begin{array}{l}-0.011^{*} \\
(0.006)\end{array}$ & $\begin{array}{l}-0.010^{*} \\
(0.006)\end{array}$ & $\begin{array}{l}-0.011^{*} \\
(0.006)\end{array}$ & $\begin{array}{l}-0.015^{* * * *} \\
(0.005)\end{array}$ & -0.046 \\
\hline THC & $\begin{array}{l}0.470 * * * \\
(0.087)\end{array}$ & $\begin{array}{l}0.360 * * * \\
(0.088)\end{array}$ & $\begin{array}{l}0.466^{* * * *} \\
(0.088)\end{array}$ & $\begin{array}{l}0.349 * * * \\
(0.086)\end{array}$ & $\begin{array}{l}0.280 * * * \\
(0.078)\end{array}$ & 0.856 \\
\hline CRISIS*THC & $\begin{array}{l}0.084^{*} \\
(0.045)\end{array}$ & $\begin{array}{l}0.093 * * \\
(0.045)\end{array}$ & $\begin{array}{l}0.084 * \\
(0.045)\end{array}$ & $\begin{array}{l}0.093 * * \\
(0.045)\end{array}$ & $\begin{array}{l}0.083 * * \\
(0.042)\end{array}$ & 0.254 \\
\hline$V O L$ & $\begin{array}{l}9.010 * * * \\
(0.466)\end{array}$ & $\begin{array}{l}9.120 * * * \\
(0.476)\end{array}$ & $\begin{array}{l}8.980 * * * \\
(0.469)\end{array}$ & $\begin{array}{l}9.110 * * * \\
(0.477)\end{array}$ & $\begin{array}{l}9.150 * * * \\
(0.347)\end{array}$ & 27.982 \\
\hline$R O A$ & $\begin{array}{l}-0.084 * * * \\
(0.027)\end{array}$ & $\begin{array}{l}-0.087 * * \\
(0.034)\end{array}$ & $\begin{array}{l}-0.092 * * * \\
(0.029)\end{array}$ & $\begin{array}{l}-0.091 * * * \\
(0.034)\end{array}$ & $\begin{array}{l}-0.082 * * * \\
(0.017)\end{array}$ & -0.251 \\
\hline SIZE & $\begin{array}{l}-0.054 * * * \\
(0.009)\end{array}$ & $\begin{array}{l}-0.049 * * * \\
(0.009)\end{array}$ & $\begin{array}{l}-0.075^{* * * *} \\
(0.019)\end{array}$ & $\begin{array}{l}-0.073 * * * \\
(0.020)\end{array}$ & $\begin{array}{l}-0.050 * * * \\
(0.008)\end{array}$ & -0.153 \\
\hline DI_FOCUS & $\begin{array}{l}0.466 * * * \\
(0.102)\end{array}$ & $\begin{array}{l}0.332 * * * \\
(0.100)\end{array}$ & $\begin{array}{l}0.474 * * * \\
(0.101)\end{array}$ & $\begin{array}{l}0.332 * * * \\
(0.099)\end{array}$ & $\begin{array}{l}0.243 * * * \\
(0.089)\end{array}$ & 0.743 \\
\hline$A G E$ & $\begin{array}{l}0.161 * * * \\
(0.019)\end{array}$ & $\begin{array}{l}0.160 * * * \\
(0.019)\end{array}$ & $\begin{array}{l}0.158^{* * * *} \\
(0.019)\end{array}$ & $\begin{array}{l}0.157 * * * \\
(0.019)\end{array}$ & $\begin{array}{l}0.160 * * * \\
(0.017)\end{array}$ & 0.489 \\
\hline ISSUE_SIZE & $\begin{array}{l}0.038 * * * \\
(0.006)\end{array}$ & $\begin{array}{l}0.037 * * * \\
(0.006)\end{array}$ & $\begin{array}{l}0.039 * * * \\
(0.006)\end{array}$ & $\begin{array}{l}0.038 * * * \\
(0.006)\end{array}$ & $\begin{array}{l}0.036^{* * *} \\
(0.006)\end{array}$ & 0.110 \\
\hline$C A L L$ & $\begin{array}{l}0.004 \\
(0.021)\end{array}$ & $\begin{array}{l}0.006 \\
(0.021)\end{array}$ & $\begin{array}{l}0.003 \\
(0.021)\end{array}$ & $\begin{array}{l}0.006 \\
(0.021)\end{array}$ & $\begin{array}{l}0.008 \\
(0.021)\end{array}$ & 0.024 \\
\hline PUT & $\begin{array}{l}-0.312 * * * \\
(0.067)\end{array}$ & $\begin{array}{l}-0.317^{* * * *} \\
(0.067)\end{array}$ & $\begin{array}{l}-0.298 * * * \\
(0.067)\end{array}$ & $\begin{array}{l}-0.305^{* * * *} \\
(0.067)\end{array}$ & $\begin{array}{l}-0.324 * * * \\
(0.071)\end{array}$ & -0.991 \\
\hline SENIOR & $\begin{array}{l}-0.273 * * * \\
(0.028)\end{array}$ & $\begin{array}{l}-0.272 * * * \\
(0.028)\end{array}$ & $\begin{array}{l}-0.273 * * * \\
(0.028)\end{array}$ & $\begin{array}{l}-0.272 * * * \\
(0.028)\end{array}$ & $\begin{array}{l}-0.268 * * * \\
(0.027)\end{array}$ & -0.820 \\
\hline CRISIS & $\begin{array}{l}0.306^{* * *} \\
(0.024)\end{array}$ & $\begin{array}{l}0.291 * * * \\
(0.024)\end{array}$ & $\begin{array}{l}0.304 * * * \\
(0.024)\end{array}$ & $\begin{array}{l}0.290 * * * \\
(0.024)\end{array}$ & $\begin{array}{l}0.291 * * * \\
(0.023)\end{array}$ & 0.890 \\
\hline$S P R E A D_{t-1}$ & $\begin{array}{l}0.672 * * * \\
(0.010)\end{array}$ & $\begin{array}{l}0.674 * * * \\
(0.010)\end{array}$ & $\begin{array}{l}0.672 * * * \\
(0.010)\end{array}$ & $\begin{array}{l}0.673 * * * \\
(0.010)\end{array}$ & $\begin{array}{l}0.673 * * * \\
(0.008)\end{array}$ & \\
\hline INTERCEPT & $\begin{array}{l}-0.028 \\
(0.227)\end{array}$ & $\begin{array}{l}-0.004 \\
(0.241)\end{array}$ & $\begin{array}{l}0.014 \\
(0.230)\end{array}$ & $\begin{array}{l}0.086 \\
(0.251)\end{array}$ & $\begin{array}{l}0.112 \\
(0.200)\end{array}$ & \\
\hline$B O N D S$ & $\begin{array}{l}0.0381 \\
(0.217)\end{array}$ & $\begin{array}{l}-0.016 \\
(0.258)\end{array}$ & & & & \\
\hline$L O G \_T B O$ & & & $\begin{array}{l}0.024 \\
(0.018)\end{array}$ & $\begin{array}{l}0.026 \\
(0.019)\end{array}$ & & \\
\hline LEVERAGE & & $\begin{array}{l}0.001 \\
(0.002)\end{array}$ & & $\begin{array}{l}-0.000 \\
(0.002)\end{array}$ & & \\
\hline No. of observations & 8,223 & 8,223 & 8,223 & 8,223 & 8,223 & \\
\hline$R^{2}$ & 0.702 & 0.701 & 0.702 & 0.701 & 0.702 & \\
\hline
\end{tabular}

Note: Column 1 contains the coefficient estimates for the model augmented by BONDS (the ratio of bonds outstanding to total liabilities) for the issuing HC. Column 2 displays coefficient estimates for the model that includes BONDS and LEVERAGE (equity capital ratio of the issuing HC). Column 3 presents estimates for the model augmented by $L O G \_T B O$ (logarithm of the HC's total bonds outstanding). Column 4 presents estimates for the model that include $L O G_{-} T B \bar{O}$ and 
LEVERAGE (see Section 3). White's (1980) standard errors are in parentheses. Coefficient estimates are the short-run effects. Column 6 contain the long-run effects for the 3SLS estimates (the short-run effects divided by the adjustment term; 1-the coefficient of SPREAD $D_{t-1}$ ). Variables definitions are as in Table 1, except for SIZE, AGE, and ISSUE_SIZE. SIZE is the logarithm of total assets in thousands of dollars, $A G E$ is calculated by adding 1 to the bond's age in years and then taking the logarithm. ISSUE_SIZE is the logarithm of the bond's issue size in thousands of dollars. *, **, and *** indicate statistical significances at the $10 \%, 5 \%$, and $1 \%$ level, respectively. 